\title{
The Copts in Italy: Migration and Generosity
}

\author{
Beatrice Nicolini
}

\section{$\mathbf{1}$ \\ The Coptic Church and Italy}

The term copt, initially without any confessional connotations, derives from the Arab term qutb, quft, qift, and more precisely from the Arab translation of the Greek term aiguptios imported through the Latin term cophti, cophtitae. At the beginning of the Arab domination along the Mediterranean African regions, this term indicated Egypt's original inhabitants in order to distinguish them from rum, which was referred to those Egyptians of Greek-Byzantine origins. ${ }^{1}$ Copts were simply thought as Egyptians.

The Copts once formed a large Christian community, from the Nile to the Middle East to the Horn of Africa. They became a minority after the Muslim occupation of Egypt in the seventh century; they remained an integral part of the Egyptian world.

The relationship between Italy and the Coptic community in the Middle East is ancient and intense. Coptic recorded history ended around the fourteenth century (Ayad, 2016). In the fifteenth century, the Council of Florence, held between 1438 and 1445, decided to invite the first official delegation to Europe. The first Coptic manuscripts were introduced in Italy and soon the Copts were persuaded to submit to the papacy. In 1630, there were Copts in Italy although, on the whole, they were very reluctant to travel to Europe or, indeed, to travel at all (Hamilton, 2006). Nevertheless, the Coptic Diaspora showed that upward mobility could be achieved without loss of heritage identity (Mahmood, 2012). Until the nineteenth century there have not been many sources. Occasional sources from Arab authors or from Western travelers or pilgrims were the only available information. Gian Battista Brocchi (who visited Egypt in 1822-26), Alessandro Ricci (1817-22) and Ippolito Rossellini (1828-19) visited Egypt and reported about the Copts. These explorers, through their adventures, described the Coptic Churches they visited and explained the main theological differences between the Coptic Orthodox, the Coptic

1 A special thanks to L. Zanfrini, G. Valtolina, A. Melcangi, R. Bottoni and P. Schellenbaum for their precious comments. Transcriptions and transliterations are here simplified and as in consulted sources and texts. 
Catholic and the Roman Catholic Churches. It must be remembered that the three Italian explorers were driven by prejudice typical of their epoch and, in their reports, wrote about the Copts as "heretics", "schismatics", "ignorant", "intolerant", "extremely poor"; besides, monks were believed to have permission to get married. In 1824, Vatican City opened a parochiality for the Catholic Copts, but it remained a theory and was never realized. On March 15, 1895 Pope Leo XIII (1810-1903) appointed vicar apostolic G. Makarios who took the name of bishop Cyril. Once elected, Cyril guided a delegation to Rome asking for the realization of the parochiality. Pope Leo XIII agreed to this request through the apostolic letter "Christi Domini" of 26 November 1895, which officially restored the Coptic patriarch of Alexandria of Egypt. Catholic Coptic priests can get married except for the bishops; the majority of them lives in Egypt and in Sudan; and, as stressed above, very few migrated to other countries.

The migration fluxes in Italy were historically mainly from Egypt due to the persecutions and the violence against the Coptic community. Today, the presence of the Copts in Italy is supposed to be around 70,000 people scattered along the territory (International Congress of Coptic Studies, 2016; Ambrosiana Community Report, 2018). The majority is centered around the Milan area. The total number of the Copts in Italy remains quite obscure also because of the non-compulsory religious identity clarification in Italian censuses (Bottoni, 2019). In France, there are about 250,000 Copts, and in Great Britain 20,000. In total, Egyptian migrants in Italy are estimated to be around 119,00o (Istat, 2018), with the Copts representing almost one third of this total. The role of this religious community is very important: the Copts not only give to their parishioners, but they offer shelter to local communities, thus valorizing the churches and the places where they pray and live. Violence hits but does not prevail. The religious structure facilitates positive assimilation. Copts Churches are present on the Italian territory as follows: in Tuscany, Florence, St. Mina Coptic Orthodox church in Scandicci; in Lazio, St. George, and St. Mark in Rome; in Lombardy, monastery Anba Shenouda in Lacchiarella, St. Mary \& St. Antonius in Cinisello Balsamo, St. Mark in Milan; in Piedmont, St. Mary, Turin.

The recent presence of the Copts in Italy dates back to the 1970s; pastoral activities started in those years, too. In 1973, the historical meeting between Pope Paul VI (1897-1978) and Shenuda III, Pope of the Copts, marked the conclusion of a route that lasted fourteen centuries. Since 1982, the Copts have not 
increased their presence in the Milan area, where today there are two bishops, one monastery, the Episcopal seat in Lacchiarella, close to the city of Milan, and twenty parishes and other communities are growing quickly. Moreover, in 1995, a second reality organized by the Coptic community in Italy, in collaboration with the Patriarch Tawadros II (Waqih Sobhi Bakky Suleiman, born in 1952), 118th Pope of the Copt Orthodox Church, did appear in Turin, Rome, Florence and its surroundings. It was divided into some main areas: Rome, Florence, Perugia, Bologna and Reggio Emilia, Turin (plus the other centers of Genova, La Spezia and Bari), with the central seat in Rome under the guide of the bishop Barnaba El Soryany. The Coptic diocese of Rome has some 7,000 worshippers. The Coptic Church found a welcoming environment in Italy, where it was possible to show all the vitality of a Christian reality that survived centuries of persecution, an intense liturgical life focused on the radical experience of the monasticism of the desert, and an active interest for the mutual support of the faithful in various aspects of social and family life. The Coptic Church is in favor of the theological dialogue between Christians and supports many initiatives for Christian realities in the Middle East. Cinisello Balsamo, Milan, is the Episcopal seat with Anba Kirolos, metropolitan bishop of Europe, who died in 2017 and strongly contributed to the construction and realization of ten churches in the Milan area. Today (2019), the new bishop is Anba Antonius. Visiting the Episcopal seat is very instructive to try to understand the Coptic world. From outside, it looks like a former factory that remained as it used to be. Inside, it has been totally renovated: in the main corpus, today, there is a beautiful Coptic church that can seat up to 500 people. All around there are buildings for parishioners' gatherings after the celebrations, for catechism, priests' residential houses, and the bishop residence. Joining a Coptic Mass is a fascinating experience; the whole community sings and dialogues with the priest in Coptic, in Greek and in Italian. The community is very young, with many families with more than three children; this is one of the main reasons of the great attention to the religious education of the young Coptic generations. Furthermore, it is interesting to note the new positive experiences of the open oratories during summer. Here, the children join the priests, as the Coptic structures remain open during summertime, while others usually close. Among the nine Coptic churches in Milan, only one is Catholic in origin, which is the one in Senato Street, in the very center of Milan, dedicated to St. Mark. The other churches have been restored from abandoned buildings, such as the one in Gorla and in Saronno. In Gorla, a dismissed industrial area has been bought through a judicial action and two industrial sheds were united so that it could host all the parishioners. In Saronno, instead, a formerly abandoned gym became a place to deal drugs and created many problems to the local 
inhabitants. The Copt community helped Saronno through the acquisition of this degraded space. The proof of this positive initiative was that the Via Crucis celebrated by Cardinal Angelo Scola through the pastoral zone 4 during the route between the two stations saw the alternation in carrying the Cross of St. Charles containing the Saint Nail of a Coptic exponent, a Romanian, and a Russian: important signs of the multi-religious reality. The commitment to redevelop abandoned spaces is among the main tasks of the Coptic Church in Italy. This is the answer of a migrant community in touch with its identity, which never stops dialoguing with the surrounding communities and attempts to solve many troubled situations in order to set constructive examples to many people.

Since 2011, hundreds of Egyptian Copts have been killed in sectarian clashes, and many homes and businesses have been destroyed. In just one province (Minya in Egypt), 77 cases of sectarian attacks against Copts between 2011 and 2018 have been documented. Copts migrated to Italy from Egypt between $195^{2}$ and 1975 because they could not find jobs due to discrimination. Their wives could not go to a Coptic gynaecologist because Coptic gynaecologists could not practice - and this is just one of the examples of daily discrimination faced by Copts in Egypt. Equality did not exist at work or in the streets. If a woman was seen walking around wearing a cross, she would have to face harassment. It was forbidden to park cars outside of any church. Copts have been, and still are, strangers in their own country. In Egypt, rarely are documents released to Copts, and they prohibit people from converting to Christianity by putting them in jail. The terrorist attacks against Copts in Egypt during these recent years were all firmly condemned by the Italian governments and by the main religious communities. According to bishop al-Soryani, all Christians expressed their grief in the demonstration against the terroristic attacks in 2000 in Kosheh, where 21 Copts died, and on 7 January 2010 in Naga Hammadi, where eight Copts were shot dead in the Upper Egyptian city of Naga Hammadi, right in front of the cathedral. On that occasion, Italy condemned violence against Coptic Christians in Egypt, with Foreign Minister F. Frattini during his second mandate (2008-11) saying he would personally take up the matter with his Egyptian counterpart on a visit to Cairo. The violence perpetrated against the Christian Copt community in Egypt was horrific and outrageous after six Copts and one Muslim police officer were killed, apparently by Muslims, in the south of the country. At least nine more Copts were wounded, two of them seriously, 
when drive-by attackers raked a crowd of shoppers in a southern Egypt town with gunfire, on the eve of their Christmas celebrations. Rome and Milan's Coptic community organized demonstrations in various parts of the country to express support to Coptic Christians in Egypt after the New Year's Eve bomb attack on a church in Alexandria in 2017 (Cucca, 2018). Milan saw a sit-in in front of the Egyptian embassy in Porpora Street, with some demonstrators blocking the road for a few hours. Tensions increased when Muslim citizens arrived, and police intervention was required. No demonstration received the support of the Coptic diocese of Milan, which consists of about 12,000 Copts guided by Anba Antonius. The bishop did not approve of the sit-in from a spiritual point of view since he disagreed with the idea of priests leaving the church to demonstrate in the streets. There were two main reasons. First, it must be noted that the Coptic Church is not a political entity; second, the way to support the Copts in Egypt is through prayer and sending aid to the affected families. This is why Coptic churches of the diocese of Milan held a mass prayer on 8 January 2018 for the dead and the wounded of the Alexandria attack. The diocese agreed to meet Egypt's ambassador to Italy and the consul general in Milan at the monastery of Anba Shenouda in Lachiarella to express condolences and discuss the current situation of the Copts in Egypt. They stressed the urgency of an education reform, the spread of the concept of citizenship regardless of religious affiliation, changing the rules for church construction, upholding the rights of non-Muslim families, and other measures aimed at eliminating inequality between Copts and Muslims. The Coptic Church asked them not to make any comments so as not to make the situation worse and endanger the lives of the Copts in Egypt. Fear pervaded in the Milan demonstration. All those interviewed were reluctant to give their names, afraid of endangering relatives in Egypt. They denounced the Egyptian government's conspiracy of silence, which, they said, failed to put an end to the discriminations against the Copts, though it had been stipulated in the Constitution. Interviewees cited the need to obtain a presidential decree to build a church and pointed out the low number of Copts in parliament, as well as the fact that key positions remain inaccessible to Copts. Many of the Egyptians who joined the sit-in had emigrated because of religious discrimination, which had prevented them either from finding a job or from advancing in their careers.

Rome was also ripe with Coptic reactions to the incident. Unlike Milan, the Rome diocese organized a January 2018 demonstration in support of Coptic Egyptians and against terrorism and religious discrimination. Criticism started before the event, when al-Soryani asked Muslims and Jews not to take part in the Repubblica Square sit-in, saying it was the wish of the Copts to mourn within their community. He invited them to organize a different demonstration. 
About 1,00o Copts from different areas, including Turin, Florence, and Reggio Emilia, gathered amid massive security measures. Prayers in Arabic and Italian were recited by bishop al-Soryan and priests from all over the Diocese. Another recent attack was in Minya, in Egypt, on 2 November 2018. A prayer in St. Peter's Basilica preceded the Rome demonstration, and Catholics could show solidarity with the global Christian community. Common requests to the Egyptian government by Copts from both Milan and Rome were cancelling the field of religion in identity cards, changing regulations on the construction and restoration of churches, changing the school curriculum to include the pre-Islamic period, which used to be omitted, and other reforms aiming at eliminating religious discrimination. On 9 July 2018, the President Sergio Mattarella received at the Quirinale Tawadros II, Pope of Alexandria and of San Mark. Pope Tawadros II, Pope of the Copts, came from Bari, and then he went in the Basilica of St. Paul Outside the Walls in Rome with Anba Barnaba, Anba Antonius and Anba Wisa. Ambassadors of Rome and of Vatican City, Hisham Badr and Mahmud Sami with a diplomatic delegation with Wael Selim. During the celebration, Anghelos Bisha became the new bishop of Florence, beloved by his parishioners when he was in Rome. Pope Tawadros II appointed the new Coptic bishop of Milan, Anba Antonius, as successor of Anba Kirolos. He graduated in medicine at Assiut University and at Ain Shams University in Cairo. He chose the monastic life and he lived in the Anba Shenouda monastery in Milan serving many churches of the Coptic community. Anba Antonius is the new bishop of Milan and its surroundings, with the Venice exemption.

\section{4}

\section{Conclusions}

While the Coptic tradition and presence constitutes an ancient and strong reality in Italy, today the majority of Italians are substantially ignoring Copts' lives and activities. The striking lack of recent sources and information, compared to the richness of Middle Eastern sources of such a lively religious reality in Italy, is a symptom of the deep necessity for further research on this important topic. The history of religious and political persecutions and violence is a tragedy that affected all Copts, most of all in Egypt. Throughout their Diaspora history, the principle of unity as a nation represented Copts' only hope, and it was only within the context of the nation-state that the point of unity could be possible across all the religious and cultural differences. The creation and the necessity for the definition of religious minorities was a dramatic passage in Christian Copts' history. They refused to be classified as a religious minority and claimed the recognition of their identity not on a religious basis but on a 
national one. This topic is so vast that it could represent a further issue of research alone. Moreover, the Coptic presence in Italy, as described above, can surely be seen as positive, since the Coptic Church not only takes care of its parishioners, but is also very generous with the whole environment and the surrounding communities. Coptic migration and generosity are positive and potential issues to a future communication and a future understanding between religious as well as between social communities in Italy. 